\title{
Effect of Carissa opaca leaves extract on lipid peroxidation, antioxidant activity and reproductive hormones in male rats
}

\author{
Sumaira Sahreen ${ }^{1,2}$, Muhammad Rashid Khan ${ }^{2}$, Rahmat Ali Khan ${ }^{2,3^{*}}$ and Naseer Ali Shah ${ }^{2}$
}

\begin{abstract}
Background: Carissa opaca leaves are traditionally used in the treatment of male dysfunction and hormonal disorder as well as in oxidative stress in Pakistan and Asia. The present study was designed to assess the protective effects of methanolic extract of Carissa opaca leaves (MLC) on carbon tetrachloride $\left(\mathrm{CCl}_{4}\right)$-induced reproductive stress in male rats and bioactive constituents responsible for the activity.

Methods: $\mathrm{CCl}_{4}$ was induced in 42 male rats for eight weeks and checked the protective efficacy of methanolic extract of Carissa opaca leaves at various hormonal imbalances, alteration of antioxidant enzymes, DNA fragmentation levels and lipid peroxidation caused testicular fibrosis in testis while High performance Liquid Chromatography (HPLC) was used for detection of bioactive components.

Results: HPLC characterization revealed the presence of isoquercitin, hyperoside, vitexin, myricetin and kaempherol. $\mathrm{CCl}_{4}$ caused significant alteration in the secretion of reproductive hormones. Activity of antioxidant enzymes viz; catalase, superoxide dimutase and phase II metabolizing enzymes including glutathione peroxidase, glutathione reductase and reduced glutathione was decreased while DNA fragmentation, hydrogen per oxide contents and thiobarbituric acid reactive substances (TBARS) were increased with $\mathrm{CCl}_{4}$ treatment. Co-administration of $100 \mathrm{mg} / \mathrm{kg}$ and $200 \mathrm{mg} / \mathrm{kg}$ b.w. MLC effectively ameliorated the alterations in the biochemical markers; hormonal and molecular levels.

Conclusion: Protective effects of methanolic extract of Carissa opaca against $\mathrm{CCl}_{4}$ induced antioxidant and hormonal dysfunction which might be due to bioactive compound present in extract.
\end{abstract}

Keywords: $\mathrm{CCl}_{4}$, Carissa opaca, TBARS, LH, DNA fragmentation

\section{Background}

During the last decade, considerable attention was given to the involvement of oxygen free radicals in various diseases. There is no doubt that reactive oxygen species (ROS) play an important role in pathological changes in the liver, particularly in the case of alcoholic and toxic liver diseases [1]. Biological membranes are particularly prone to ROS effect. The peroxidation of unsaturated fatty acids in biological membranes leads to the decrease of membrane fluidity and the disruption of membrane

\footnotetext{
* Correspondence: Rahmatgul_81@yahoo.com

${ }^{2}$ Department of Biochemistry, Faculty of Biological Sciences, Quaid-i-Azam University, Islamabad, Pakistan

${ }^{3}$ Department of Biotechnology, Faculty of Biological Sciences, University of Science and Technology Bannu, Khyber Pakhtunkhwa KPK 28100, Pakistan Full list of author information is available at the end of the article
}

integrity and function. Such peroxidation effect is implicated in serious pathological changes [2]. $\mathrm{CCl}_{4}$ is an industrial solvent causes tissue damages in various tissues of experimental animals. $\mathrm{CCl}_{4}$ requires bioactivation by phase I cytochrome P450 system to form reactive metabolic radicals. These free radicals can bind with polyunsaturated fatty acid (PUFA) of sperm membrane to generate lipid peroxides that are highly reactive, change enzyme activity and finally induce injury or necrosis $[3,4]$. Several endogenous protective mechanisms have evolved to limit ROS effect and the damage caused by them [5]. However, when this protection is not complete, or when the formation of ROS is excessive, additional protective mechanisms of dietary antioxidants may be of a great importance. Therefore, many natural and synthetic

\section{Biomed Central}


agents possessing antioxidative properties have been proposed to prevent and treat infertility and reproductive hormonal imbalance induced by oxidative stress [6]. There is increasing evidence of the protective role of hydroxy and polyhydroxy organic compounds, particularly from vegetables, fruits and some herbs.

Plants are well-known excellent perspectives for the discovery of new therapeutical products. In recent years, an ample interest has been developed in finding natural antioxidants from commonly available wild plants, fruits and vegetables that were generally mistreated $[7,8]$ as well as an important role in detoxification of free radicals induced lung injuries and fibrosis in experimental animal's model. Carissa opaca Stapf ex Hanes a 2-3 meter tall evergreen shrub containing glabrous fruits widely found in Pakistan [9]. Traditionally this plant is used for the treatment of asthma [10], hepatitis [11], diarrhea [12] and renal dysfunction [13]. The present study was conducted to examine the toxic upshots of $\mathrm{CCl}_{4}$ plus to compare the beneficial effects of plant extracts on reproductive hormonal disturbance and activity of antioxidant enzymes in various experimental groups. In this respect, several parameters regarding the testicular injury and fibrosis were studied.

\section{Methods and materials}

\section{Plant collection}

C. opaca leaves were collected in March 2011 from the Quaid-i-Azam University Islamabad, Pakistan, recognized by their local names and validated by Dr. Mir Ajab Khan, Department of Plant Sciences, Quaid-i-Azam University, Islamabad. A voucher specimen was deposited at the Herbarium of Pakistan Quaid-i-Azam University, Islamabad Pakistan for future reference.

\section{Extract preparation}

The collected plant leaves were cleaned and dried under shade for fifteen days. Willy Mill of 60-mesh size was used to prepare powder of dried samples and then $5 \mathrm{~kg}$ powdered plant sample was extracted twice with $10 \mathrm{~L}$ of $95 \%$ methanol at $25^{\circ} \mathrm{C}$ for $48 \mathrm{~h}$. For filtration Whatman No. 1 filter paper was used and then filtrate was concentrated on rotary evaporator (Panchun Scientific Co., Kaohsiung, Taiwan) under reduced pressure at $40^{\circ} \mathrm{C}$ and dry extract was stored at $4^{\circ} \mathrm{C}$ for further in vivo investigation.

\section{Phytochemical investigation}

\section{High performance liquid chromatogrhy (HPLC)}

$50 \mathrm{mg}$ of fine powder was extracted with $6 \mathrm{ml}$ of $25 \%$ hydrochloric acid and $20 \mathrm{ml}$ methanol for $1 \mathrm{~h}$. The obtained extract was filtered to a volumetric flask and diluted to $100 \mathrm{ml}$ with methanol. $10 \mu \mathrm{l}$ was injected into HPLC column (20RBAX ECLIPSE, XDB-C18, $5 \mu \mathrm{m}$; $4.6 \times 150 \mathrm{~mm}$, Agilent USA) with UV-VIS Spectra-
Focus detector, injector-auto sampler. Solvent A $(0.05 \%$ trifluoroacetic acid) and solvent B (0.038\% trifluoroacetic acid in $83 \%$ acetonitrile $(\mathrm{v} / \mathrm{v})$ with the following gradient: 0-5 $\mathrm{min}, 15 \% \mathrm{~B}$ in $\mathrm{A}, 5-10 \mathrm{~min}, 70 \% \mathrm{~B}$ in $\mathrm{A}, 10-15$ $\mathrm{min}, 70 \% \mathrm{~B}$ in $\mathrm{A}$. The flow rate was $1 \mathrm{ml} / \mathrm{min}$ and injection volume was $10 \mu \mathrm{l}$. Various standard compounds including rutin, myricetin, vitexin, orientin, hyperoside, isovitexin, isoquercetin, luteolin, apigenin, kaempherol, and luteolin-7-glucoside were run for comparative detection and optimized. The calibration curves were defined for each compound in the range of sample quantity 0.02-0.5 $\mu$ g. All samples were assayed in triplicate.

\section{Experimental plan}

Six-week-old male Sprague Dawley rats weighing $180 \pm$ $10 \mathrm{~g}$ were provided with food and water ad libitum and kept at $20-22^{\circ} \mathrm{C}$ on a 12 -h light-dark cycle. All experimental procedures involving animals were conducted in accordance with the guidelines of National Institutes of Health (NIH guidelines). The study protocol were approved by Ethical committee of Quaid-i-Azam University Islamabad. The rats were acclimatized to laboratory condition for 7 days before commencement of experiment. For chronic toxicity eight week experiment was designed. 42 male albino rats were randomly divided into seven groups (6 rats of each group). Administration of $\mathrm{CCl}_{4}\left(0.5 \mathrm{ml} / \mathrm{kg}\right.$ b.w., $20 \% \mathrm{CCl}_{4} /$ olive oil) was intraperitoneally (i.p.) twice a week for eight weeks. At the same time, the rats were administered individually silymarin (50 mg/kg b.w.) and extract (100, $200 \mathrm{mg} / \mathrm{kg}$ b.w.) orally twice a week for eight weeks.

\section{Experimental protocol}

Following dosing plan was adapted for the study.

Group I: the normal control received only feed

Group II: Olive oil (0.5 ml/kg b.w., i.p.) + DMSO

$(0.5 \mathrm{ml} / \mathrm{kg}$ b.w. orally)

Group III: $\mathrm{CCl}_{4}$ twice a week $(0.5 \mathrm{ml} / \mathrm{kg}$ b.w., i.p., $20 \%$ $\mathrm{CCl}_{4}$ /olive oil)

Group IV: $\mathrm{CCl}_{4}$ twice a week $(0.5 \mathrm{ml} / \mathrm{kg}$ b.w., i.p. $)+$ sylimarin (50 mg/kg b.w., orally)

Group V: $\mathrm{CCl}_{4}$ twice a week $(0.5 \mathrm{ml} / \mathrm{kg}$ b.w., i.p. $)+$ MLC (100 mg/kg b.w., orally)

Group VI: $\mathrm{CCl}_{4}$ twice a week $(0.5 \mathrm{ml} / \mathrm{kg}$ b.w., i.p. $)+$ MLC (200 mg/kg b.w., orally)

At the end of eight weeks, after $24 \mathrm{~h}$ of the last treatment, Urine was collected and stored at $-70^{\circ} \mathrm{C}$ for further analysis, and then animals were given chloroform anesthesia and dissected from ventral side. All the animals were sacrificed; blood was drawn prior to the excision of organ tissues. The serum was stored at $-80^{\circ} \mathrm{C}$ after separation until it was assayed as described below. After taking blood the testis were removed and washed in ice cold saline. Subsequently, half of the organs were 
treated with liquid nitrogen and stored at $-80^{\circ} \mathrm{C}$ for further enzymatic and DNA damage analysis while the other portion was processed for histology.

\section{Assesment of reproductive hormones and lipid profile of serum}

Serum analysis of testicular hormones like FSH, LH, testosterone, prolactin and esteradiol were radioimmunoassayed by using Marseille Cedax 9 France Kits and Czch Republic Kits from Immunotech Company. Then again, lipid profile such as Triglycerides, total cholesterol, LDL and LDH waere estimated by using standard AMP diagnostic kits (Stattogger Strasse 31b 8045 Graz, Austria).

\section{Assessment of antioxidant enzymes}

$10 \%$ homogenate of tissue was prepared in $100 \mathrm{mM}$ $\mathrm{KH}_{2} \mathrm{PO}_{4}$ buffer containing $1 \mathrm{mM}$ EDTA (pH 7.4) and centrifuged at $12,000 \times \mathrm{g}$ for $30 \mathrm{~min}$ at $4^{\circ} \mathrm{C}$. The supernatant was collected and used for the following parameters as described below.

\section{Catalase assay (CAT)}

CAT activities were determined by the method of Chance and Maehly [14] with some modifications. The reaction solution of CAT activities contained: $2.5 \mathrm{ml}$ of $50 \mathrm{mM}$ phosphate buffer ( $\mathrm{pH} 5.0$ ), $0.4 \mathrm{ml}$ of $5.9 \mathrm{mM}$ $\mathrm{H}_{2} \mathrm{O}_{2}$ and $0.1 \mathrm{ml}$ enzyme extract. Changes in absorbance of the reaction solution at $240 \mathrm{~nm}$ were determined after one minute. One unit of CAT activity was defined as an absorbance change of 0.01 as units $/ \mathrm{min}$.

\section{Peroxidase assay (POD)}

Activities of POD were determined by the method of Chance and Maehly [14] with some modifications. The POD reaction solution contained: $2.5 \mathrm{ml}$ of $50 \mathrm{mM}$ phosphate buffer ( $\mathrm{pH} 5.0$ ), $0.1 \mathrm{ml}$ of $20 \mathrm{mM}$ guaiacol, $0.3 \mathrm{ml}$ of $40 \mathrm{mM} \mathrm{H} \mathrm{O}_{2}$ and $0.1 \mathrm{ml}$ enzyme extract. Changes in absorbance of the reaction solution at $470 \mathrm{~nm}$ were determined after one minute. One unit of POD activity was defined as an absorbance change of 0.01 units $/ \mathrm{min}$.

\section{Superoxide dismutase assay (SOD)}

SOD activity was estimated by the method of Kakkar et al. [15]. Reaction mixture of this method contained: $0.1 \mathrm{ml}$ of phenazine methosulphate $(186 \mu \mathrm{M}), 1.2 \mathrm{ml}$ of sodium pyrophosphate buffer (0.052 mM; pH 7.0), $0.3 \mathrm{ml}$ of supernatant after centrifugation $(1500 \times \mathrm{g}$ for $10 \mathrm{~min}$ followed by $10000 \times \mathrm{g}$ for $15 \mathrm{~min}$ ) of testis homogenate was added to the reaction mixture. Enzyme reaction was initiated by adding $0.2 \mathrm{ml}$ of NADH $(780 \mu \mathrm{M})$ and stopped after $1 \mathrm{~min}$ by adding $1 \mathrm{ml}$ of glacial acetic acid. Amount of chromogen formed was measured by recording color intensity at $560 \mathrm{~nm}$. Results are expressed in units/mg protein.

\section{Glutathione-S-transferase assay (GST)}

Glutathione-S-transferase activity was assayed by the method of Habig et al. [16]. The reaction mixture consisted of $1.475 \mathrm{ml}$ phosphate buffer $(0.1 \mathrm{~mol}, \mathrm{pH} 6.5), 0.2 \mathrm{ml}$ reduced glutathione $(1 \mathrm{mM}), 0.025 \mathrm{ml}(\mathrm{CDNB})(1 \mathrm{mM})$ and $0.3 \mathrm{ml}$ of homogenate in a total volume of $2.0 \mathrm{ml}$. The changes in the absorbance were recorded at $340 \mathrm{~nm}$ and enzymes activity was calculated as nM CDNB conjugate formed $/ \mathrm{min} / \mathrm{mg}$ protein using a molar extinction coefficient of $9.6 \times 10^{3} \mathrm{M}^{-1} \mathrm{~cm}^{-1}$.

\section{Glutathione reductase assay (GR)}

Glutathione reductase activity was determined by method of Carlberg and Mannervik [17]. The reaction mixture consisted of $1.65 \mathrm{ml}$ phosphate buffer: $(0.1 \mathrm{~mol}$; pH 7.6), $0.1 \mathrm{ml}$ EDTA (0.5 mM), $0.05 \mathrm{ml}$ oxidized glutathione $(1 \mathrm{mM}), 0.1 \mathrm{ml} \mathrm{NADPH}(0.1 \mathrm{mmol})$ and $0.1 \mathrm{ml}$ of homogenate in a total volume of $2 \mathrm{ml}$. Enzyme activity was quantitated at $25^{\circ} \mathrm{C}$ by measuring disappearance of NADPH at $340 \mathrm{~nm}$ and was calculated as nM $\mathrm{NADPH}$ oxidized $/ \mathrm{min} / \mathrm{mg}$ protein using molar extinction coefficient of $6.22 \times 10^{3} \mathrm{M}^{-1} \mathrm{~cm}^{-1}$.

\section{Glutathione peroxidase assay (GPx)}

Glutathione peroxidase activity was assayed by the method of Mohandas et al. [18]. The reaction mixture consisted of $1.49 \mathrm{ml}$ phosphate buffer (0.1 M; pH 7.4), $0.1 \mathrm{ml}$ EDTA (1 mM), $0.1 \mathrm{ml}$ sodium azide $(1 \mathrm{mM}), 0.05 \mathrm{ml}$ glutathione reductase $(1 \mathrm{IU} / \mathrm{ml}), 0.05 \mathrm{ml} \mathrm{GSH}(1 \mathrm{mM}), 0.1 \mathrm{ml}$ $\mathrm{NADPH}(0.2 \mathrm{mM}), 0.01 \mathrm{ml} \mathrm{H}_{2} \mathrm{O}_{2}(0.25 \mathrm{mM})$ and $0.1 \mathrm{ml}$ of homogenate in a total volume of $2 \mathrm{ml}$. The disappearance of NADPH at $340 \mathrm{~nm}$ was recorded at $25^{\circ} \mathrm{C}$. Enzyme activity was calculated as nM NADPH oxidized/ $\mathrm{min} / \mathrm{mg}$ protein using molar extinction coefficient of $6.22 \times 10^{3} \mathrm{M}^{-1} \mathrm{~cm}^{-1}$.

\section{Quinone reductase assay (QR)}

The activity of quinone reductase was determined by the method of Benson et al. [19]. The $3.0 \mathrm{ml}$ reaction mixture consisted of $2.13 \mathrm{ml}$ Tris- $\mathrm{HCl}$ buffer $(25 \mathrm{mM}$; $\mathrm{pH}$ 7.4), $0.7 \mathrm{ml} \mathrm{BSA}, 0.1 \mathrm{ml}$ FAD, $0.02 \mathrm{ml} \mathrm{NADPH}$ $(0.1 \mathrm{mM})$, and $0.1 \mathrm{ml}$ of homogenate. The reduction of dichlorophenolindophenol (DCPIP) was recorded at $600 \mathrm{~nm}$ and enzyme activity was calculated as $\mathrm{nM}$ of DCPIP reduced $/ \mathrm{min} / \mathrm{mg}$ protein using molar extinction coefficient of $2.1 \times 10^{4} \mathrm{M}^{-1} \mathrm{~cm}^{-1}$.

\section{Reduced glutathione assay (GSH)}

Reduced glutathione was estimated by the method of Jollow et al. [20]. $1.0 \mathrm{ml}$ sample of homogenate was precipitated with $1.0 \mathrm{ml}$ of (4\%) sulfosalicylic acid. The samples were kept at $4^{\circ} \mathrm{C}$ for $1 \mathrm{~h}$ and then centrifuged at $1200 \times \mathrm{g}$ for $20 \mathrm{~min}$ at $4^{\circ} \mathrm{C}$. The total volume of $3.0 \mathrm{ml}$ assay mixture contained $0.1 \mathrm{ml}$ filtered aliquot, $2.7 \mathrm{ml}$ 
phosphate buffer (0.1 M; pH 7.4) and $0.2 \mathrm{ml} \mathrm{DTNB}$ (100 mM). The yellow color developed was read immediately at $412 \mathrm{~nm}$ on a SmartSpecTM plus Spectrophotometer. It was expressed as $\mu \mathrm{M}$ GSH/g tissue.

\section{Estimation of lipid peroxidation assay (TBARS/LPO)}

The assay for lipid peroxidation was carried out following the modified method of Iqbal et al. [21]. The reaction mixture in a total volume of $1.0 \mathrm{ml}$ contained $0.58 \mathrm{ml}$ phosphate buffer (0.1 M; pH 7.4), $0.2 \mathrm{ml}$ homogenate sample, $0.2 \mathrm{ml}$ ascorbic acid $(100 \mathrm{mM})$, and $0.02 \mathrm{ml}$ ferric chloride $(100 \mathrm{mM})$. The reaction mixture was incubated at $37^{\circ} \mathrm{C}$ in a shaking water bath for $1 \mathrm{~h}$. The reaction was stopped by addition of $1.0 \mathrm{ml} 10 \%$ trichloroacetic acid. Following addition of $1.0 \mathrm{ml} 0.67 \%$ thiobarbituric acid, all the tubes were placed in boiling water bath for $20 \mathrm{~min}$ and then shifted to crushed ice-bath before centrifuging at $2500 \times \mathrm{g}$ for $10 \mathrm{~min}$. The amount of TBARS formed in each of the samples was assessed by measuring optical density of the supernatant at $535 \mathrm{~nm}$ using spectrophotometer against a reagent blank. The results were expressed as $\mathrm{nM}$ TBARS $/ \mathrm{min} / \mathrm{mg}$ tissue at $37^{\circ} \mathrm{C}$ using molar extinction coefficient of $1.56 \times 10^{5} \mathrm{M}^{-1} \mathrm{~cm}^{-1}$.

\section{Hydrogen peroxide assay $\left(\mathrm{H}_{2} \mathrm{O}_{2}\right)$}

Hydrogen peroxide $\left(\mathrm{H}_{2} \mathrm{O}_{2}\right)$ was assayed by $\mathrm{H}_{2} \mathrm{O}_{2}$-mediated horseradish peroxidase-dependent oxidation of phenol red by the method of Pick and Keisari [22]. $2.0 \mathrm{ml}$ of homogenate sample was suspended in $1.0 \mathrm{ml}$ of solution containing phenol red $(0.28 \mathrm{nM})$, horse radish peroxidase (8.5 units), dextrose $(5.5 \mathrm{nM})$ and phosphate buffer $(0.05 \mathrm{M} ; \mathrm{pH} 7.0)$ and were incubated at $37^{\circ} \mathrm{C}$ for $60 \mathrm{~min}$. The reaction was stopped by the addition of $0.01 \mathrm{ml}$ of $\mathrm{NaOH}(10 \mathrm{~N})$ and then centrifuged at $800 \times \mathrm{g}$ for $5 \mathrm{~min}$. The absorbance of the supernatant was recorded at $610 \mathrm{~nm}$ against a reagent blank. The quantity of $\mathrm{H}_{2} \mathrm{O}_{2}$ produced was expressed as $\mathrm{nM} \mathrm{H}_{2} \mathrm{O}_{2} / \mathrm{min} / \mathrm{mg}$ tissue based on the standard curve of $\mathrm{H}_{2} \mathrm{O}_{2}$ oxidized phenol red.

\section{Molecular studies}

DNA had been isolated and its fragmentation percent was quantified in molecular studies of in vivo toxicity.

\section{DNA fragmentation assay with diphenylamine reaction}

DNA fragmentation from tissue extract was determined using the procedure of Wu et al. [23]. $100 \mathrm{mg}$ tissue was homogenized in TTE solution. $0.1 \mathrm{ml}$ of homogenate was labeled B, centrifuged at $200 \times \mathrm{g}$ at $4^{\circ} \mathrm{C}$ for $10 \mathrm{~min}$, got supernatant labeled $\mathrm{S}$. S tubes were centrifuged at $20,000 \times \mathrm{g}$ for $10 \mathrm{~min}$ at $4^{\circ} \mathrm{C}$ to separate intact chromatin, was labeled T. $1.0 \mathrm{ml}$ of $25 \%$ TCA was added in all tubes T, B, S and incubated over night at $4^{\circ} \mathrm{C}$. After incubation precipitated DNA was recovered by pelleting for $10 \mathrm{~min}$ at $18,000 \times \mathrm{g}$ at $4^{\circ} \mathrm{C}$. $160 \mu \mathrm{l}$ of $5 \% \mathrm{TCA}$ was added to each pellet and heated for $15 \mathrm{~min}$ at $90^{\circ} \mathrm{C}$ then $320 \mu \mathrm{l}$ of freshly prepared DPA solution was added, vortexed and incubated for $4 \mathrm{hr} 37^{\circ} \mathrm{C}$. Optical density was read at $600 \mathrm{~nm}$ with a spectrophotometer (Smart $\operatorname{spec}^{\mathrm{rm}}$ Plus, catalog \# 170-2525).

\section{DNA Isolations and ladder assay}

DNA was isolated by using the methods of $\mathrm{Wu}$ et al. [23]. $100 \mathrm{mg}$ of tissue in a petri dish was washed with DNA Buffer and homogenized in $1 \mathrm{ml}$ lysis buffer. $100 \mu \mathrm{l}$ of proteinase $\mathrm{K}(10 \mathrm{mg} / \mathrm{ml})$ and $240 \mu \mathrm{l} 10 \%$ SDS, shaked gently, and incubate overnight at $45^{\circ} \mathrm{C}$ in a water bath then $0.4 \mathrm{ml}$ of phenol, was added shaked for 5-10 min, and centrifuge at $3000 \mathrm{rpm}$ for $5 \mathrm{~min}$ at $10^{\circ} \mathrm{C}$. Supernatant was mixed with $1.2 \mathrm{ml}$ phenol, $1.2 \mathrm{ml}$ Chloroform/isoamyl alcohol (24:1); shaked for 5-10 min, and centrifuged at 3000 $\mathrm{rpm}$ for $5 \mathrm{~min}$ at $10^{\circ} \mathrm{C}$. $25 \mu \mathrm{l}$ of $3 \mathrm{M}$ sodium acetate $(\mathrm{pH} 5.2)$ and $5 \mathrm{ml}$ ethanol was added with supernatant, shake until DNA was precipitated. DNA was washed with $70 \%$ ethanol, dried, dissolved in TE buffer and its concentration checked at 260 and $280 \mathrm{~nm} .5 \mu \mathrm{g}$ of total DNA and $0.5 \mu \mathrm{g}$ DNA standard per well were loaded on $1.5 \%$ agarose gel containing ethidium bromide. Electrophoresis was performed for 45 min with $100 \mathrm{~V}$ batteries, and DNA was observed under digital gel doc system and photographed.

\section{Histopathological study of tissue}

After weighting the portion specifies for histology small pieces of each tissue was fixed for 3-4 h in fixative sera followed by dehydration with ascending grades of alcohol (80\%, 90\%, and 100\%) and transferred in cedar wood oil. When tissue becomes clear then all tissues were embedded in paraplast and prepared blocks for further microtomy. 3-4 $\mu \mathrm{m}$ thin slides were prepared with microtome; wax was removed, stained with hemotoxilin-eosin and photographed under light microscope at 10x and 40x.

\section{Statistical analysis}

To find the different treatment effects of in vivo studies one way analysis of variance was carried by computer software SPSS 13.0. Level of significance among the various treatments was determined by LSD at $0.05 \%$ level of probability.

\section{Results}

\section{Phytochemical determination}

\section{High performance liquid chromatography (HPLC)}

In the present study, HPLC-UV was preferred for the qualitative as well as quantitative analysis of methanolic extract of C. opaca leaves. All experimental conditions were optimized to get the chromatograms with better resolution within a short resolution time and maximum UV absorption of sample and flavonoid standard compounds were quantified by assimilation of peak areas at $220 \mathrm{~nm}$ within runtime of 20 minutes as summarized in 
Table 1 Linear regression analysis of eleven standard flavonoids

\begin{tabular}{lllll}
\hline Compound & Retention time & Regression analysis & $\mathbf{R}$ & Linear range (ppm) \\
\hline Rutin & 8.7 & $\mathrm{y}=12571.3 x-16.62$ & 0.9873 & $10-250$ \\
\hline Myricetin & 18.5 & $\mathrm{y}=9643.4 x-11.07$ & 0.9919 & $10-200$ \\
\hline Vitexin & 2.5 & $\mathrm{y}=23085.1 \mathrm{x}+3.72$ & 0.9932 & $10-100$ \\
\hline Orientin & 2.75 & $\mathrm{y}=36421.0 x+2.88$ & 0.9869 & $25-500$ \\
\hline Hyperoside & 12.5 & $\mathrm{y}=22758.9 x+1.56$ & 0.9865 & $10-250$ \\
\hline Isovitexin & 3.7 & $\mathrm{y}=31604.2 x+0.98$ & 0.9741 & $5-150$ \\
\hline Luteolin & 2.01 & $\mathrm{y}=19348.6 x+2.08$ & 0.9532 & $5-100$ \\
\hline Isoquercetin & 6 & $\mathrm{y}=26785.6 x+1.60$ & $5-500$ \\
\hline Apigenin & 4.7 & $\mathrm{y}=10623.5 x-9.82$ & 0.9616 & $25-250$ \\
\hline Kaempherol & 3.4 & $\mathrm{y}=26182.8 x-+2.33$ & 0.9765 & $10-500$ \\
\hline Luteolin-7-glucoside & 1.6 & $\mathrm{y}=11434.6 x-10.72$ & 0.9417 & $5-100$
\end{tabular}

Values are Mean \pm SD (03 number).

Table 1. The conditions used directed towards the good separation of peaks that may be identified in the chromatogram as apigenin $\left(R_{t}=4.7\right)$, myricetin $\left(R_{t}=18.5\right)$, vitexin $\left(R_{t}=2.5\right)$, orientin $\left(R_{t}=2.75\right)$, hyperoside $\left(R_{t}=\right.$ 12.5), isovitexin $\left(R_{t}=3.7\right)$, isoquercetin $\left(R_{t}=6\right)$, rutin $\left(R_{t}=\right.$ 8.7), luteolin $\left(R_{t}=2.01\right)$, kaempherol $\left(R_{t}=3.4\right)$, luteolin-7glucoside $\left(R_{t}=1.6\right)$. A sample of $10 \mu$ l of solution was injected to the instrument and identification was done by comparing the obtained peaks of chromatogram of samples with the peaks of standard flavonoids in respect to retention time and UV-spectra. The chromatogram determining flavonoids components of different fractions of C. opaca leaves in Figure 1. Table 2 summarized the flavonoids found in methanolic fraction of C. opaca leaves. There were some peaks having different retention time could not be identified; however, based on their chromatographic behaviors and UV spectra, they may correspond to unknown flavonoids compounds as presented in respective chromatogram.

\section{In Vivo investigation}

Previous studies reported that liver is not the just target organ of $\mathrm{CCl}_{4}$; it can actually distress other vital organs including kidney, lungs, heart and testis. Consequently, the intention of the current study was to assess the $\mathrm{CCl}_{4}$ as one of the male reproductive toxicant, hence alteration in the male reproductive hormones, antioxidant levels, lipid profile of serum and histopathological changes of the testis were investigated.

Effects of $\mathrm{MLC}$ against $\mathrm{CCl}_{4}$ induced testicular toxicity in rat The current study was paying attention on the estimation of ameliorating potential of $C$. opaca leaves against testicular toxicity provoked by $\mathrm{CCl}_{4}$. The biomarkers for

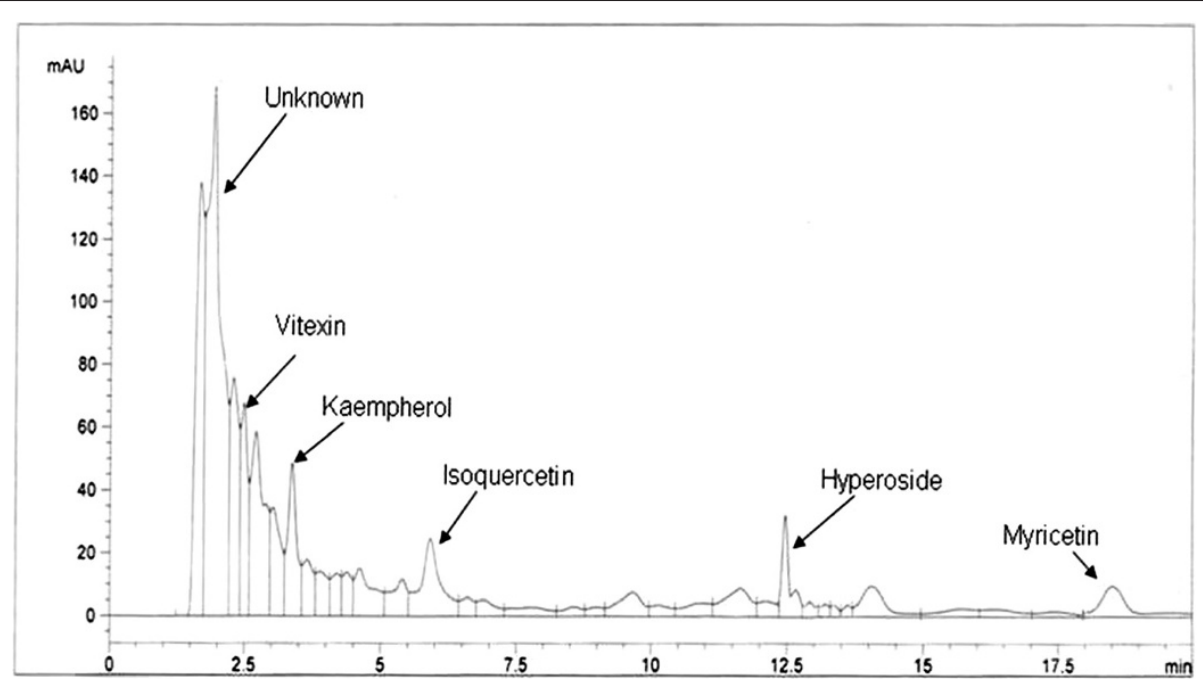

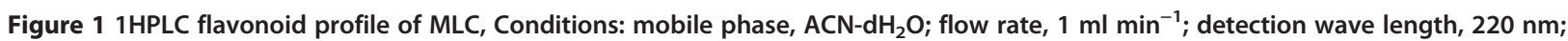
column temperature, $36^{\circ} \mathrm{C}$; injection volume, $10 \mu \mathrm{l}$. 
Table 2 Assessment of flavonoids in methanolic extract of Carissa opaca leaves extract

\begin{tabular}{lll}
\hline Compound & Retention time & Concentration $\boldsymbol{\mu g} / \mathbf{m g}$ of dry weight \\
\hline Isoquercitin & 6 & 0.119 \\
\hline Hyperoside & 12.5 & 0.062 \\
\hline Vitexin & 2.5 & 0.053 \\
\hline Myricetin & 18.5 & 0.172 \\
\hline Kaempherol & 3.4 & 0.08 \\
\hline
\end{tabular}

Values are Mean \pm SD (03 number).

testicular toxicity evaluation were based on serological studies, antioxidant enzyme levels of tissue, genotoxicity and histological variation of testis.

\section{Effects of MLC on male reproductive hormones of rats}

Data from the serological markers for reproductive status such as testosterone, luteinizing hormone (LH), follicle stimulating hormone (FSH), prolactin and estradiol is summarized in Table $3 . \mathrm{CCl}_{4}$ intoxication drastically $(\mathrm{p}<0.05)$ reduced the serum level of testosterone, $\mathrm{LH}$ and $\mathrm{FSH}$, while notably $(\mathrm{p}<0.05)$ increased the intensity of prolactin and estradiol. The serum level of above said reproductive hormones was re-established $(\mathrm{p}<0.05)$ by oral administration of $100 \mathrm{mg} / \mathrm{kg}$ b.w., $200 \mathrm{mg} / \mathrm{kg}$ b.w., MLC near to control group. $50 \mathrm{mg} / \mathrm{kg}$ body weight of silymarin treatment erased $\mathrm{CCl}_{4}$ intoxication and restored the level of all tested reproductive hormones in serum of rats.

\section{Effects of MLC on lipid panel changes}

Table 4 summarizes protective effects of MLC against $\mathrm{CCl}_{4}$ induced toxicity in lipids profile of serum. For lipid parameters total triglycerides, total cholesterol, HDL, and LDL were investigated.CCl ${ }_{4}$ disputation markedly increased the levels of triglycerides, total cholesterol, and LDL cholesterol while decreased $(\mathrm{p}<0.01)$ HDL cholesterol as against the control group. Treatment of MCL cancelled the toxicity of $\mathrm{CCl}_{4}$ thus, restoring the serum level of total triglycerides, total cholesterol, HDL, and LDL towards the control group. Treatment with silymarin also produced similar results.

\section{Effects of MLC on testis enzymatic antioxidant levels}

Oxidative stress produced by $\mathrm{CCl}_{4}$ upsets the cellular antioxidant defense system. The protective effects of MLC against $\mathrm{CCl}_{4}$ toxicity on the antioxidant profile are presented in Table 5. Administration of $\mathrm{CCl}_{4}$ for eight weeks caused noteworthy $(\mathrm{p}<0.05)$ decrease in the tissue soluble protein and CAT, POD and SOD activities as opposite to control group. Post-treatment of $100 \mathrm{mg} / \mathrm{kg}$ b.w., $200 \mathrm{mg} /$ $\mathrm{kg}$ b.w., MLC markedly ameliorated the affects of $\mathrm{CCl}_{4}$ intoxication, and distinctly enhanced $(\mathrm{p}<0.05)$ testicular protein and CAT, POD and SOD levels of testicular tissue. Lipid peroxidation is umpired via free radicals produced by $\mathrm{CCl}_{4}$ intoxication. The significant decline in $\mathrm{H}_{2} \mathrm{O}_{2}$ and TBARS level of testicular tissue corroborates with protective power $100 \mathrm{mg} / \mathrm{kg}$ b.w., $200 \mathrm{mg} / \mathrm{kg}$ b.w., MLC against testicular $\mathrm{CCl}_{4}$ induced lipid peroxidation in testis tissue Similar protective effects were reported, while treating with silymarin.

Alterations in phase II antioxidant metabolizing enzymes viz; GST, GPx, GR, GSH and QR as well as DNA fragmentation\% testicular tissues of rat are demonstrated in Table 6. Chronic administration of $\mathrm{CCl}_{4}$, extensively $(\mathrm{p}<0.05)$ abridged the glutathione status of GST, GPx, GR, GSH and QR whereas, percentage of DNA fragmentation was increased in comparison to non treated control group. Post-treatment with $100 \mathrm{mg} / \mathrm{kg}$ b.w., $200 \mathrm{mg} / \mathrm{kg}$ b.w., MLC attenuated the intoxication of $\mathrm{CCl}_{4}$ and restored the enzymes activity near to control rats. Silymarin treatment markedly lessened the DNA fragmentation\% while, increased the GST, GSH, GR, GPx and QR activation similar to the effects of $100 \mathrm{mg} / \mathrm{kg}$ b.w., $200 \mathrm{mg} / \mathrm{kg}$ b.w., MLC.

\section{Effects of MLC on DNA damages (ladder assay)}

Protective effects of different doses of MLC versus $\mathrm{CCl}_{4}$ induced DNA damage in the testicular tissues of rats is shown by DNA ladder assay in Figure 2. Extensive DNA breakages in testis were portrayed by the treatment of

Table 3 Effects of MLC on male reproductive hormonal level

\begin{tabular}{llllll}
\hline Group & $\begin{array}{l}\text { Testosterone } \\
(\mathbf{n g} / \mathbf{m l})\end{array}$ & $\begin{array}{l}\text { Luteinizing } \\
\text { Hormone }(\mathbf{n g} / \mathbf{m l})\end{array}$ & $\begin{array}{l}\text { Follicle Stimulating } \\
\text { Hormone }(\mathbf{n g} / \mathbf{m l})\end{array}$ & $\begin{array}{l}\text { Prolactin } \\
(\mathbf{n g} / \mathbf{m l})\end{array}$ & $\begin{array}{l}\text { Estradiol } \\
(\mathbf{n g} / \mathbf{m l})\end{array}$ \\
\hline Control & $4.2 \pm 0.07 \mathrm{~d}$ & $2.28 \pm 0.09 \mathrm{c}$ & $40.37 \pm 0.14 \mathrm{~h}$ & $10.43 \pm 0.34 \mathrm{e}$ & $17.43 \pm 0.32 \mathrm{~g}$ \\
\hline Oil $+\mathrm{DMSO}$ & $4.1 \pm 0.13 \mathrm{~d}$ & $2.23 \pm 0.01 \mathrm{c}$ & $39.12 \pm 0.36 \mathrm{~h}$ & $11.23 \pm 0.32 \mathrm{e}$ & $15.24 \pm 0.43 \mathrm{~g}$ \\
\hline $\mathrm{CCl}_{4}$ & $1.9 \pm 0.08 \mathrm{a}$ & $1.10 \pm 0.08 \mathrm{a}$ & $16.68 \pm 0.21 \mathrm{a}$ & $22.11 \pm 0.44 \mathrm{a}$ & $30.16 \pm 0.65 \mathrm{a}$ \\
\hline $\mathrm{Sily}+\mathrm{CCl} 4$ & $3.5 \pm 0.10 \mathrm{c}$ & $1.89 \pm 0.12 \mathrm{~b}$ & $32.87 \pm 0.48 \mathrm{~g}$ & $14.4 \pm 0.22 \mathrm{~d}$ & $20.23 \pm 0.63 \mathrm{f}$ \\
\hline $100 \mathrm{mg} / \mathrm{kg}$ b.w. MLC $+\mathrm{CCl}_{4}$ & $2.2 \pm 0.03 \mathrm{c}$ & $1.74 \pm 0.05 \mathrm{~b}$ & $23.04 \pm 0.35 \mathrm{c}$ & $16.01 \pm 0.50 \mathrm{c}$ & $24.18 \pm 0.29 \mathrm{c}$ \\
\hline $200 \mathrm{mg} / \mathrm{kg}$ b.w. MLC $+\mathrm{CCl}_{4}$ & $3.30 \pm 0.23 \mathrm{c}$ & $2.01 \pm 0.13 \mathrm{~b}$ & $28.15 \pm 0.49 \mathrm{f}$ & $16.23 \pm 0.21 \mathrm{c}$ & $22.43 \pm 0.25 \mathrm{~d}$ \\
\hline $\mathrm{MLC}$ alone & $4.0 \pm 0.07 \mathrm{~d}$ & $2.36 \pm 0.09 \mathrm{c}$ & $40.85 \pm 0.62 \mathrm{~h}$ & $12.27 \pm 0.30 \mathrm{e}$ & $14.37 \pm 0.30 \mathrm{~g}$ \\
\hline
\end{tabular}

Values are Mean \pm SD (06 number), Sily = Silymarin.

a-f (Means with different letters) indicate significance at $p<0.05$. 
Table 4 Effects of MLC on lipid profile

\begin{tabular}{lllll}
\hline Group & Triglycerides $(\mathbf{m g} / \mathbf{d l})$ & Total Cholesterol $(\mathbf{m g} / \mathbf{d l})$ & HDL $(\mathbf{m g} / \mathbf{d l})$ & LDL $(\mathbf{m g} / \mathbf{d l})$ \\
\hline Control & $130.13 \pm 2.97 \mathrm{e}$ & $39.15 \pm 1.43 e$ & $32.31 \pm 1.08 \mathrm{~d}$ & $15.34 \pm 1.34 \mathrm{~d}$ \\
\hline Oil + DMSO & $128.76 \pm 2.45 \mathrm{e}$ & $40.24 \pm 1.34 \mathrm{e}$ & $30.32 \pm 1.73 \mathrm{~d}$ & $13.56 \pm 1.11 \mathrm{~d}$ \\
\hline $\mathrm{CCl}$ & $230.19 \pm 2.08 \mathrm{a}$ & $78.99 \pm 1.05 \mathrm{a}$ & $52.36 \pm 1.04 \mathrm{a}$ & $30.61 \pm 2.04 \mathrm{a}$ \\
\hline $\mathrm{Sily}+\mathrm{CCl}{ }_{4}$ & $159.32 \pm 2.42 \mathrm{~d}$ & $49.23 \pm 2.33 \mathrm{~d}$ & $40.33 \pm 1.27 \mathrm{c}$ & $20.76 \pm 1.73 \mathrm{c}$ \\
\hline $100 \mathrm{mg} / \mathrm{kg}$ b.w. MLC $+\mathrm{CCl}_{4}$ & $190.06 \pm 4.41 \mathrm{~b}$ & $60.73 \pm 1.72 \mathrm{~b}$ & $48.23 \pm 1.12 \mathrm{~b}$ & $25.26 \pm 1.95 \mathrm{~b}$ \\
\hline $200 \mathrm{mg} / \mathrm{kg}$ b.w. MLC $+\mathrm{CCl}_{4}$ & $168.99 \pm 2.22 \mathrm{c}$ & $52.84 \pm 2.62 \mathrm{c}$ & $44.84 \pm 1.69 \mathrm{c}$ & $22.33 \pm 1.41 \mathrm{c}$ \\
\hline $\mathrm{MLC}$ alone & $127.19 \pm 1.33 \mathrm{e}$ & $39.65 \pm 1.28 \mathrm{e}$ & $29.47 \pm 1.36 \mathrm{~d}$ & $12.15 \pm 1.11 \mathrm{~d}$ \\
\hline
\end{tabular}

Values are Mean \pm SD (06 number). Sily = Silymarin.

a-e (Means with different letters) indicate significance at $p<0.05$.

$\mathrm{CCl}_{4}$ to rats. Post-administration of silymarin and MLC prevented the DNA damages induced by $\mathrm{CCl}_{4}$ indicating the protective effects of C. opaca leave.

\section{Effects of MLC on testis histoarchitecture}

The histoarchitecture of testis after different treatments is presented in Figure 3. Light microscope evaluation of $\mathrm{H}$ \& E stain showed normal testicular architecture possessing normal seminiferous tubules, normal concentration of germ cells, sperms with normal morphology and concentration and inconspicuous sertoli cells (Figure 3A). The $\mathrm{CCl}_{4}$ intoxication resulted in ruthless testicular injuries with imperative decrease in germ cells, vacuolization of germinative epithelium and dislocated interstitial cells away from basement membrane and seminiferous tubules as shown in Figure 3B. The silymarin group also showed almost normal structure of testis as compare to $\mathrm{CCl}_{4}$ intoxicated group (Figure 3C). Groups treated MLC showed improved concentration of sperms and stabilization of organized seminiferous tubules (Figure 3D). The results obtained from histological architecture were in consistency with the hormonal studies as well as antioxidant status.

\section{Discussion}

Oxidative stress induced by an increase in free radicals and/or decrease in antioxidant defenses is well documented in animal model [24,25]. $\mathrm{CCl}_{4}$, a typical toxic agent, exerts its toxic effects by the generation of free

Table 5 Effects of MLC on tissue proteins and antioxidant enzyme levels

\begin{tabular}{|c|c|c|c|c|c|c|}
\hline Group & $\begin{array}{l}\text { Protein } \\
\text { ( } \mu \mathrm{g} / \mathrm{mg} \text { tissue) }\end{array}$ & $\begin{array}{l}\text { CAT } \\
(\mathrm{U} / \mathrm{min})\end{array}$ & $\begin{array}{l}\text { POD } \\
\text { (U/min) }\end{array}$ & $\begin{array}{l}\text { SOD } \\
\text { (U/mg protein) }\end{array}$ & $\begin{array}{l}\text { TBARS } \\
\text { (nM/min/mg protein) }\end{array}$ & $\begin{array}{l}\mathrm{H}_{2} \mathrm{O}_{2} \\
(\mu \mathrm{M} / \mathrm{ml})\end{array}$ \\
\hline Control & $1.421 \pm 0.023 d$ & $3.92 \pm 0.22 d$ & $9.38 \pm 0.13 c$ & $3.08 \pm 0.23 d$ & $2.97 \pm 0.16 \mathrm{~d}$ & $1.123 \pm 0.010 c$ \\
\hline Oil + DMSO & $1.495 \pm 0.026 d$ & $4.02 \pm 0.55 d$ & $9.04 \pm 0.34 c$ & $3.12 \pm 0.14 d$ & $3.10 \pm 0.27 d$ & $1.244 \pm 0.012 c$ \\
\hline $\mathrm{CCl}_{4}$ & $0.834 \pm 0.029 a$ & $2.02 \pm 0.11 a$ & $4.76 \pm 0.51 a$ & $0.88 \pm 0.07 a$ & $5.71 \pm 0.48 a$ & $2.536 \pm 0.023 a$ \\
\hline Sily $+\mathrm{CCl}_{4}$ & $1.312 \pm 0.008 c$ & $3.54 \pm 0.34 c$ & $8.58 \pm 0.38 b$ & $2.75 \pm 0.07 c$ & $3.80 \pm 0.33 c$ & $1.560 \pm 0.091 b$ \\
\hline $100 \mathrm{mg} / \mathrm{kg}$ b.w. $\mathrm{MLC}+\mathrm{CCl}_{4}$ & $1.27 \pm 0.062 c$ & $2.9 \pm 0.17 b$ & $7.79 \pm 0.85 c$ & $1.95 \pm 0.13 c$ & $3.74 \pm 0.70 b$ & $1.30 \pm 0.069 c$ \\
\hline 200 mg/kg b.w. MLC $+\mathrm{CCl}_{4}$ & $1.344 \pm 0.073 c$ & $3.25 \pm 0.32 c$ & $8.37 \pm 0.41 b$ & $2.29 \pm 0.11 b$ & $4.01 \pm 0.25 c$ & $1.644 \pm 0.065 b$ \\
\hline MFC alone & $1.441 \pm 0.012 d$ & $3.95 \pm 0.68 d$ & $10.00 \pm 0.61 c$ & $3.63 \pm 0.13 d$ & $2.91 \pm 0.33 d$ & $1.121 \pm 0.045 c$ \\
\hline
\end{tabular}

Values are Mean \pm SD (06 number). Sily = Silymarin.

a-h (Means with different letters) indicate significance at $p<0.05$

Table 6 Effects of MLC on phase II antioxidant enzymes and DNA fragmentation

\begin{tabular}{|c|c|c|c|c|c|c|}
\hline Group & $\begin{array}{l}\text { GST } \\
\text { (nM/mg protein) }\end{array}$ & $\begin{array}{l}\text { GPx } \\
\text { (nM/mg protein) }\end{array}$ & $\begin{array}{l}\text { GR } \\
\text { (nM/mg protein) }\end{array}$ & $\begin{array}{l}\text { GSH } \\
\text { ( } \mu \mathrm{M} / \mathrm{g} \text { tissue) }\end{array}$ & $\begin{array}{l}\text { QR } \\
\text { (nM/mg protein) }\end{array}$ & \%DNA Injuries \\
\hline Control & $150.23 \pm 5.34 \mathrm{~g}$ & $110.17 \pm 4.46 f$ & $198.34 \pm 5.78 \mathrm{e}$ & $16.25 \pm 1.11 \mathrm{C}$ & $99.90 \pm 4.97 f$ & $14.53 \pm 2.57 f$ \\
\hline Oil + DMSO & $157.17 \pm 4.45 g$ & $105.55 \pm 4.55 f$ & $204.73 \pm 6.47 e$ & $15.74 \pm 1.31 \mathrm{C}$ & $107.03 \pm 4.42 f$ & $13.33 \pm 2.24 f$ \\
\hline$\overline{\mathrm{CCl}_{4}}$ & $78.37 \pm 4.33 a$ & $63.33 \pm 3.11 \mathrm{a}$ & $103.14 \pm 4.66 a$ & $9.60 \pm 1.34 a$ & $52.40 \pm 4.16 a$ & $57.50 \pm 3.34 a$ \\
\hline Sily $+\mathrm{CCl}_{4}$ & $133.67 \pm 2.43 f$ & $98.46 \pm 2.22 \mathrm{e}$ & $179.56 \pm 4.45 d$ & $13.75 \pm 0.32 b$ & $89.14 \pm 2.56 \mathrm{e}$ & $20.18 \pm 3.73 e$ \\
\hline $100 \mathrm{mg} / \mathrm{kg}$ b.w. MFC $+\mathrm{CCl}_{4}$ & $120.54 \pm 1.98 c$ & $77.39 \pm 2.92 b$ & $166.07 \pm 2.21 c$ & $20.05 \pm 0.90 c$ & $75.25 \pm 3.12 d$ & $33.30 \pm 0.25 d$ \\
\hline $200 \mathrm{mg} / \mathrm{kg}$ b.w. MFC + $\mathrm{CCl}_{4}$ & $124.12 \pm 2.81 e$ & $94.65 \pm 2.16 \mathrm{e}$ & $170.68 \pm 4.97 d$ & $13.29 \pm 0.46 b$ & $82.56 \pm 3.67 d$ & $23.56 \pm 2.36 \mathrm{e}$ \\
\hline MFC alone & $159.31 \pm 3.21 \mathrm{~g}$ & $112.40 \pm 3.26 f$ & $201.25 \pm 4.12 \mathrm{e}$ & $17.59 \pm 1.45 c$ & $109.34 \pm 2.23 f$ & $12.55 \pm 1.27 f$ \\
\hline
\end{tabular}

Values are Mean \pm SD (06 number). Sily = Silymarin.

a-f (Means with different letters) indicate significance at $p<0.05$. 


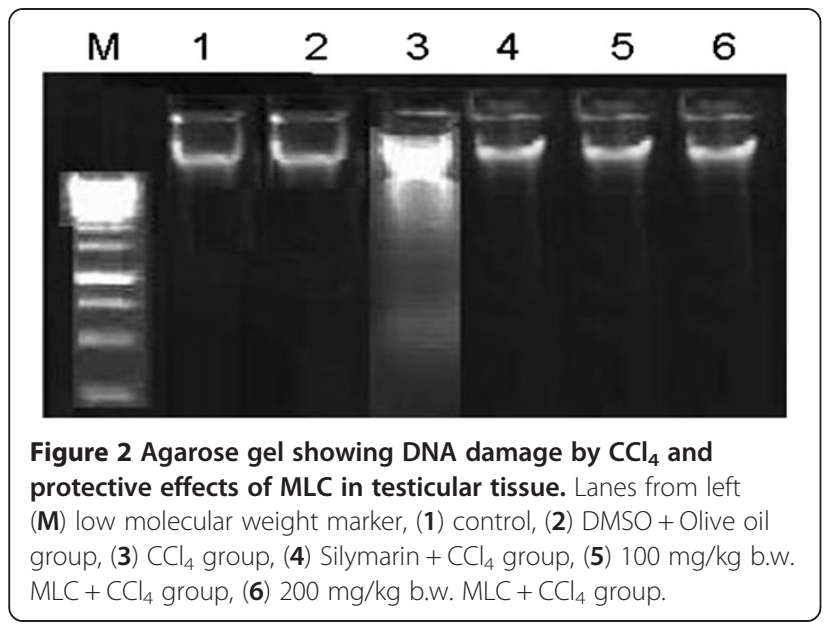

radicals. By the activation of liver cytochromes P450, $\mathrm{CCl}_{4}$ is converted into free radicals which immediately react with cell membrane [26]. This free radical not only targets liver but it can also causes free radical generation in other tissues like kidneys, heart, lung, testis, brain and blood $[27,28]$. In the current study, the proposed plan aimed to assess and examine the possibility of MLC to protect and reduce the lipid peroxidation and oxidative damages caused by $\mathrm{CCl}_{4}$ in testis tissue homogenate of male Sprague Dawley rats. The reduction of testosterone levels in serum indicates either direct effects of $\mathrm{CCl}_{4}$ at
Leydig cell level or indirect effects by disturbing the hormonal environmentat hypothalamo-pituitary axis [29] due to oxidative trauma in $\mathrm{CCl}_{4}$ treated rats. It was reported that abnormal level of intra testicular testosterones inhibits spermatogenesis [30]. Tohda et al. (2001). The production of testosterone in Leydig cells is stimulated by $\mathrm{LH}$, which activates FSH to bind with sertoli cells to stimulate spermatogenesis [31]. CCl4 intoxicated rats show the malfunctioning of pituitary to secrete FSH and $\mathrm{LH}$ indicating testicular dysfunction leading to infertility as was reported by previous results [32]. GSH levels are dependent upon the activities of glutathione reductase (GR) and NADH [33]. Glutathione system including GPx, GR, GST, as well as SOD and CAT represent a mutually loyal team of defense against ROS [34]. Enhanced lipid peroxidations expressed in terms of TBARS determine structural and functional alterations of cellular membranes [35]. In the present study, administration of various fractions of plant samples in different experimental groups improved the activities of SOD, CAT, POD, GPx, GST, GR and QR as well as non enzymatic (GSH, TBARS and $\mathrm{H}_{2} \mathrm{O}_{2}$ ) levels of $\mathrm{CCl}_{4}$-intoxicated testis towards normalcy in warfare of oxidative trauma in vivo. Hence, the present results regarding chronic toxicity of $\mathrm{CCl}_{4}$ are in accordance with previous reports [36,37], while studying the protective effects of Sonchus asper and Launeae procumbens on testis against oxidative

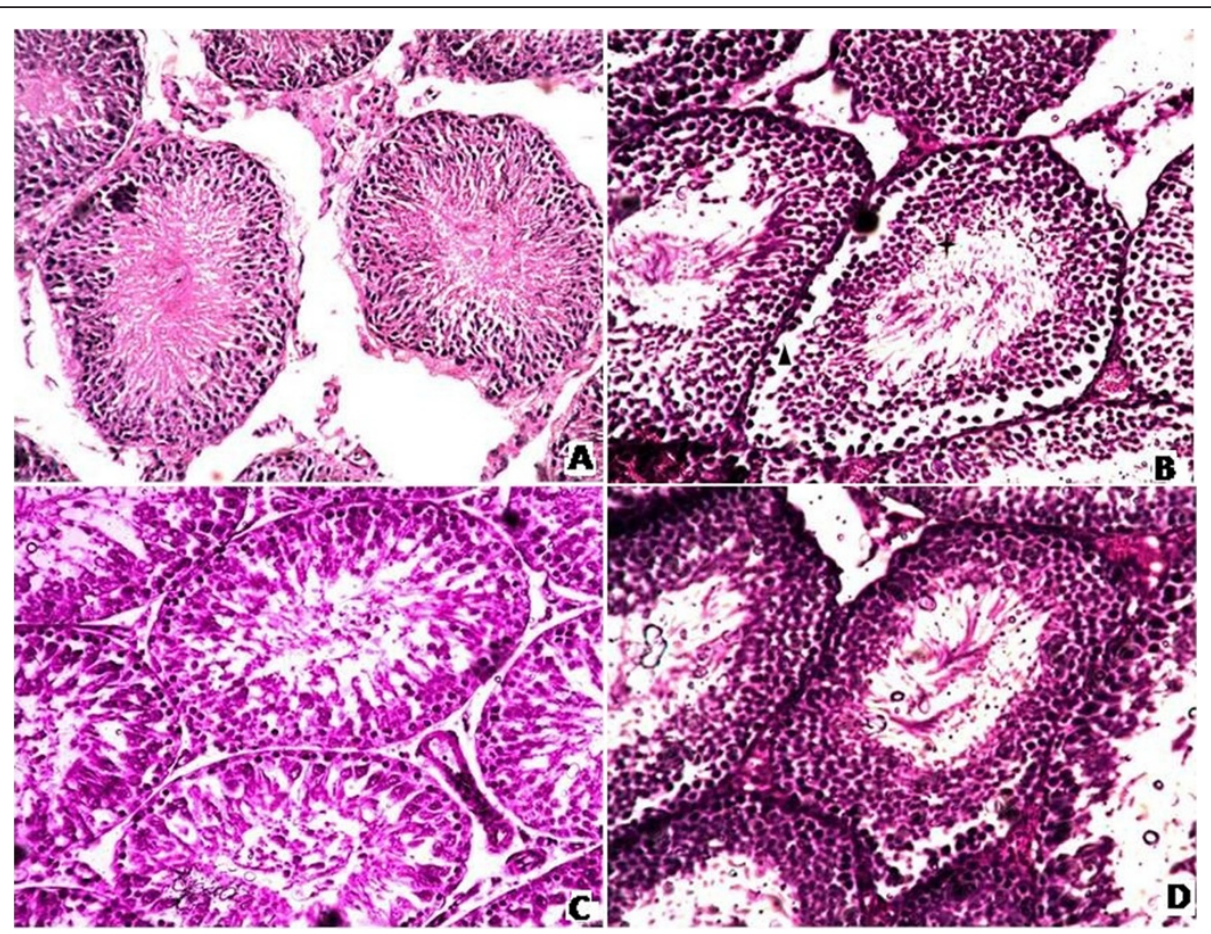

Figure 3 Microphotograph of rat testis (H \& E stain). (A) Representative section of testis from the control group showing normal histology, (B) $\mathrm{CCl}_{4}$ group, (C) Silymarin $+\mathrm{CCl}_{4}$ group, (D) $200 \mathrm{mg} / \mathrm{kg}$ b.w. $\mathrm{MLC}+\mathrm{CCl}_{4}$ group ( $\uparrow$ distorted and less concentration of germ cells, ( $\left.\mathbf{\Delta}\right)$ displaced interstitial cells away from the seminiferous tubules. 
stress of $\mathrm{CCl}_{4}$. Present study revealed that the activities of antioxidant enzymes were significantly reduced the toxication of chemical which might be due to the presence of bioactive elements like myricetin, kaempherol, isoquercetin, hyperoside and vitexin, propagating free radicals like peroxyl radicals and converting the reactive free radicals to inactive products.

It was reported that $\mathrm{CCl}_{4}$ resulted in the oxidative damage to testicular proteins in rats. Oxidative damage to proteins is very important as it can contribute secondary damage resulting in hampering the DNA repair enzymes and loss of reliability of damage polymerases during DNA replication. The DNA damage in various tissues like brain, testis and liver was reported by Manierea et al. [38]. From the present study, it can be assumed that chronic exposure of $\mathrm{CCl}_{4}$ may cause accumulation of many toxic species in cells thus damaging both DNA and lipids. In fact, treatment with various fractions of plant samples ameliorated the toxic effects on DNA as revealed by DNA fragmentation \% and ladder assay. The present study clearly augments the defensive mechanism of various samples against oxidative stress induced by $\mathrm{CCl}_{4}$ and provides confirmation about its therapeutic use in reproductive abnormalities.

Previous studies on histomorphology of testis showed shrinkage of the tubular diameter and testicular atrophy leading to degenerative changes in the germinal epithelium [39] after exposure to toxic chemical. Similar destructive effects were also accounted in $\mathrm{CCl} 4$ treated groups. The $\mathrm{CCl}_{4}$ challenge revealed testicular destruction and degeneration in histological architecture like that of profenofos that was recorded by Moustafa et al. [40] who represented damaged columnar epithelial layer, vacuolated spermatogonial cells, oedematous alterations in the seminiferous tubules and extra elongated Leydig cells. Data of the present study revealed that $\mathrm{CCl}_{4}$ may hamper continuing proliferative behavior of testicular cells thus obstruct reproduction. Deformities in spermatogenesis and partial degeneration of germ and Leydig cells have been displayed by $\mathrm{CCl}_{4}$-treated rats. However, groups administered various fractions of plant samples in different experiments demonstrated a quality active spermatogenesis, thin basement membranes and normal seminiferous tubules in most of the part of testis. Same histopathology was noticed by Manjrekar et al. [41], while evaluating the protective effects of Phyllanthus niruri Linn treatment on testis against $\mathrm{CCl} 4$ intoxication. This paper is in continuation of our previous studies Sahreen et al. [42] in which hepatoprotective effect of methanolic extract of leaves were asasessed.

\section{Conclusion}

It can be concluded from the current study that bioactive components of MLC especially flavonoids (myricetin, kaempherol, isoquercetin, hyperoside and vitexin) have the ability to recover the metabolic enzymatic activities and repair cellular injuries, thus providing scientific evidence in favor of its pharmacological use in testicular dysfunctioning.

\section{Competing interest}

The authors declare that they have no competing interests.

\section{Authors' contributions}

SS made a significant contribution to acquisition of data, analysis, drafting of the manuscript. MRK and RAK have made a substantial contribution to conception and design, interpretation of data, drafting and revising the manuscript for intellectual content. All authors read and approved the final manuscript.

\section{Author details}

${ }^{1}$ Botanical Sciences Division, Pakistan Museum of Natural History, Garden Avenue, Shakarparian, Islamabad, Pakistan. ${ }^{2}$ Department of Biochemistry, Faculty of Biological Sciences, Quaid-i-Azam University, Islamabad, Pakistan. ${ }^{3}$ Department of Biotechnology, Faculty of Biological Sciences, University of Science and Technology Bannu, Khyber Pakhtunkhwa KPK 28100, Pakistan.

Received: 14 February 2013 Accepted: 13 June 2013

Published: 20 June 2013

\section{References}

1. Das SK, Vasudevan DM: Alcohol induced oxidative stress. Life Sci 2007, 81(3):177-187.

2. Cabre M, Camps J, Paternain JL, Ferre N, Joven J: Time-course of changes in hepatic lipid peroxidation and glutathione metabolism in rats with carbon tetrachlorideinduced cirrhosis. Clin Exp Pharmacol Physiol 2000, 27(9):694-699.

3. Sikka SC, Rajasekaran M, Hellstrom WJ: Role of oxidative stress and antioxidants in male infertility. J Androl 1995, 16(6):464-468.

4. Ogeturk M, Kus I, Colakoglu N, Zararsiz I, Ithan N, Sarsilmaz M: Caffeic induced nephrotoxicity and protective effect of betaine in Sprague Dawley rats. Urology 2005, 62:353-356.

5. Sies H: Strategies of antioxidant defense. Eur J Biochem 1993, 215:213-219.

6. Kandasamy CS, Shimna TP, Mohammed BE, Arul RP, Gopal V, Venkatnarayanan R: Anti-hepatotoxic activity of polyherbal formulation in carbon tetrachloride induced toxicity in rats. RJPBCS 2010, 1:342-346.

7. Umamaheswari $\mathrm{M}$, Chatterjee TK: In vitro antioxidant activities of the fractions of Coccinnia grandis L. leaf extract Afric J Trad Compl Alter Med 2008, 5(1):61-73.

8. Kil HY, Seong ES, Ghimire BK, Chung I-M, Kwon SS, Goh EJ, Hoe K, Kim MJ, Lim JD, Lee D, Yu CY: Antioxidant and antimicrobial activities of crude sorghum extract. Food Chem 2009, 115:1234-1239.

9. Nazimuddin S, Qaiser M: Apocynaceae. Flora of Pakistan. Edited by Nasir E, Ali Sl; 1983:11-13. Department of Botany, University of Karachi, Karachi.

10. Jabeen A, Khan MA, Ahmad M, Zafar M, Ahmad F: Indigenous uses of economically important flora of Margalla Hills National Park, Islamabad Pakistan. Afric J Biotechnol 2009, 8(5):763-784.

11. Abbasi AM, Khan MA, Ahmad M, Zafar M, Khan H, Muhammad M, Sultana S: Medicinal plants for the treatment of jaundice and hepatitis based on socio-economic documentation. Afric J Biotechnol 2009, 8(8):1643-1650.

12. Adhikari BS, Babu MM, Saklani PL, Rawat GS: Distribution, use pattern and prospects for conservation of medicinal shrubs in Uttaranchal State. India J Mountain Sci 2007, 4(2):155-180.

13. Ahmad SS, Mahmood F, Dogar Z-UL-H, Khan Zl, Ahmad K, Sher M, Mustafa I, Valeem EE: Priortization of medicinal plants of Margala Hills National Park, Islamabad on the basis of available information. Pakistan J Bot 2000, 41(5):2105-2114.

14. Chance B, Maehly AC: Assay of catalase and peroxidases. Methods Enzymol 1955, 11:764-775.

15. Kakkar P, Das B, Viswanathan PN: A modified spectrophotomateric assay of superoxide dismutase. Indian J Biochem Biophys 1984, 21:130-132.

16. Habig WH, Pabst MJ, Jakoby WB: Glutathione-S-transferases: the first enzymatic step in mercapturic acid formation. J Biol Chem 1974, 249:7130-7139. 
17. Carlberg I, Mannervik EB: Glutathione level in rat brain. J Biol Chem 1975, 250:4475-4480.

18. Mohandas J, Marshal JJ, Duggin GG, Horvath JS, Tiller DJ: Differential distribution of glutathione and glutathione-related enzymes in rabbit kidney. Possible implications in analgesic nephropathy. Biochem Pharmacol 1984, 33:1801-1807.

19. Benson AM, Hunkeler MJ, Talalay P: Increase of NADPH, quinone reductase activity by dietary antioxidant: Possible role in protection against carcinogenesis and toxicity. Proceed National Academy Sci United State America 1990, 77:5216-5220.

20. Jollow DJ, Mitchell JR, Zampaglione N, Gillete JR: Bromobenzene induced liver necrosis. Protective role of glutathione and evidence for 3 , 4-bromobenzene oxide as a hepatotoxic metabolite. Pharmacol 1974, 1:151-169.

21. Iqbal M, Sharma SD, Zadeh HR, Hasan N, Abdulla M, Athar M: Glutathione metabolizing enzymes and oxidative stress in ferric nitrilotriacetate (Fe-NTA) mediated hepatic injury. Redox Rep 1996, 2:385-391.

22. Pick $A$, Keisari $Y$ : Superoxide anion and hydrogen peroxide production by chemically elicited peritoneal macrophages-induction by multiple nonphagocytic stimuli. Cell Immunol 1981, 59:301-318.

23. Wu JH, Tung YT, Chien SC, Wang SY, Kuo YH, Shyur LF, Chang ST: Effect of phytocompounds from the Heart-wood of Acacia confusa on inflammatory mediator production. J Agric Food Chem 2008, 56:1567-1573.

24. Botsoglou NA, Taitzoglou IA, Botsoglou E, Zervos I, Kokoli A, Christaki E, Nikolaidis E: Effect of long-term dietary administration of oregano and rosemary on the antioxidant status of rat serum, liver, kidney and heart after carbon tetrachloride-induced oxidative stress. J Sci Food Agric 2009, 89:1397-1406

25. Marañón G, Muñoz-Escassi B, Manley W, García C, Cayado P, de la Muela MS, Olábarri B, León R, Vara E: The effect of methyl sulphonyl methane supplementation on biomarkers of oxidative stress in sport horses following jumping exercise. Acta Vet Scand 2008, 50:45.

26. Dashti H, Jeppsson B, Hägerstrand I, Hultberg B, Srinivas U, Abdulla M, Bengmark S: Thioacetamide-and carbon tetrachloride-induced liver cirrhosis. European Surg Res 1989, 21:83-91.

27. Ozturk F, Ucar M, Ozturk IC, Vardi N, Batcioglu K: Carbon tetrachlorideinduced nephrotoxicity and protective effect of betaine in SpragueDawley rats. Urology 2003, 62:353-356.

28. Preethi KC, Kuttan R: Hepato and reno protective action of Calendula officinalis L. flower extract. Indian J Exp Biol 2009, 47:163-168.

29. Latif R, Lodhi GM, Aslam M: Effects of amlodipine on serum testosterone, testicular weight and gonado-somatic index in adult rats. J Ayub Med College Abbottabad 2008, 20(4):8-10.

30. Tohda A, Matsumiya K, Tadokoro Y, Yomogida K, Miyagawa Y, Dohmae K, Okuyama A, Nishimune Y: Testosterone suppresses spermatogenesis in juvenile spermatogonial depletion (jsd) mice. Biol Repro 2001, 65:532-537.

31. Conn PM: The molecular basis of gonadotropin releasing hormone action Endocrinology. Rev 1986, 7:3-10

32. Khan MR, Ahmed D: Protective effects of Digera muricata (L.) Mart on testis against oxidative stress of carbon tetrachloride in rat. Food Chem Toxicol 2009, 47:1393-1399.

33. Meister A, Anderson ME: Glutathione. Annals Rev Biochem 1983, 52:711-760.

34. Bandhopadhy U, Das D, Banerjee KR: Reactive oxygen species: Oxidative damage and pathogenesis. Current Sci 1999, 77:658-665.

35. Halliwell B, Aeschbach R, Loliger J, Aruoma Ol: The characterization of antioxidants. Food Chem Toxicol 1990, 33:601-617.

36. Khan RA, Khan MR, Sahreen S: Protective effects of Sonchus asper against KBrO3 induced lipid peroxidation in rats. Lipids Health Dis 2012, 27(1):164. 11.

37. Khan RA: Protective effects of Launaea procumbens on rat testis damage by $\mathrm{CCl}_{4}$. Lipids Health Dis 2012, 11:103.

38. Manierea I, Godardb T, Doergec DR, Churchwellc MI, Guffroyd M, Laurentiea M, Poula JM: DNA damage and DNA adduct formation in rat tissues following oral administration of acrylamide. Mutation Res 2005, 580:119-129.

39. Debnath D, Mandal TK: Study of quinalphos (an environmental oestrogenic insecticide) formulation (Ekalux 25 E.C.)-induced damage of the testicular tissues and antioxidant defence systems in SpragueDawley albino rats. J Applied Toxicol 2005, 20:197-204.

40. Moustafa GG, Ibrahim ZS, Hashimoto Y, M-Alkelch A, Q-Sakamoto K, Ishizuka M, Fujita S: Testicular toxicity of profenofos in matured male rats. Arch Toxicol 2007, 81:875-881.
41. Manjrekar AP, Jisha V, Bag PP, Adhikary B, Pai MM, Hegde A, Nandini M: Effect of Phyllanthus niruri Linn treatment on liver, kidney and testes in CCl4 induced hepatotoxic rats. Indian J Exp Biol 2008, 46:514-520.

42. Sahreen S, Khan MR, Khan RA: Hepatoprotective effects of methanol extract of Carissa opaca leaves on $\mathrm{CCl}_{4}$-induced damage in rat. BMC Complement Altern Med 2011, 11:48.

doi:10.1186/1476-511X-12-90

Cite this article as: Sahreen et al.: Effect of Carissa opaca leaves extract on lipid peroxidation, antioxidant activity and reproductive hormones in male rats. Lipids in Health and Disease 2013 12:90.

\section{Submit your next manuscript to BioMed Central and take full advantage of:}

- Convenient online submission

- Thorough peer review

- No space constraints or color figure charges

- Immediate publication on acceptance

- Inclusion in PubMed, CAS, Scopus and Google Scholar

- Research which is freely available for redistribution

Submit your manuscript at www.biomedcentral.com/submit
C) Biomed Central 